\title{
Analisis Kandungan Fosfor (P) Dalam Dua Varietas Kubis (Brassica oleracea) Di Daerah Lembang Bandung
}

\author{
Emma Emawati ${ }^{1}$, Nesti Septi Yani ${ }^{1}$, Idar ${ }^{1}$ \\ ${ }^{1}$ Sekolah Tinggi Farmasi Bandung, Bandung, Indonesia
}

\begin{abstract}
ABSTRAK
Fosfor merupakan nutrisi penting bagi manusia dan hewan. Selain itu, fosfor juga penting untuk pertumbuhan, pemeliharaan, perbaikan semua jaringan tubuh, dan dibutuhkan bersama dengan kalsium dan magnesium untuk pertumbuhan dan pembentukan tulang pada bayi dan anak-anak. Penelitian ini bertujuan untuk mengetahui kandungan fosfor dalam kubis putih dan ungu. Fosfor diukur dengan metode spektrofotometri Visibel, meliputi validasi analisis yang terdiri atas penetapan linieritas, batas deteksi dan batas kuantisasi, akurasi dan presisi serta analisis kadar fosfor pada sampel. Hasil penelitian menunjukan nilai linieritas 0,9991 , batas deteksi dan kuantisasi dihitung secara statistik, dengan nilai $0,38 \mu \mathrm{g} / \mathrm{ml}$ dan $1,25 \mu \mathrm{g} / \mathrm{ml}$. Presisi intra-day dan inter-day Nilaiinyatakan sebagai koefisien variansi (CV) ditentukan dalam tiga hari yang berbeda. Nilai presisi inter-day masing masing 0,$67 ; 0.60$; dan $0,80 \%$, untuk presisi intra-day $0,82 \%$. Perolehan kembali tingkat konsentrasi 2,0;3,0; 4.0; dan 5,0 ug / $\mathrm{ml}$ kisaran 86,33\% -105,01\%. Kadar fosfor dalam kubis putih 20,725 mg/g, dalam kubis ungu 14,525 $\mathrm{mg} / \mathrm{g}$ Dari hasil tersebut kadar fosfor dalam kubis putih ternyata lebih besar dibandingkan dengan kubis ungu tetapi kadar Fosfor tidak dipengaruhi oleh warna kubis. Kubis merupakan makanan kaya serat dan dapat dijadikan sebagai bahan makanan alternatif sebagai sumber fosfor.
\end{abstract}

Kata Kunci : Fosfor (p), spektrofotometri, kubis.

\begin{abstract}
Phosphorus is an essential nutrient for human and animal. In addition, phosphorus is also important for the growth, maintenance, repair of all body tissues, and is required along with calcium and magnesium for growth and bone formation in infants and children. The purpose of this study was to determine the levels of phosphorus in the cabbage white and purple. The methode used spectrophotometry visible, which conttain validation includes linierity determination, the limit of detection and limit of quantitation, accuracy and precision, and analysis of phosphorus in the sample. The results showed that linearity $\mathrm{r}$ value of 0.9991 the value of the limit of detection of $0,38 \mu \mathrm{g} / \mathrm{mL}$ and quantitation limit value of $1.25 \mu \mathrm{g} / \mathrm{mL}$, the precision inter day: $0.67 \% ; 0.60 \%$; and $0.80 \%$. and also for the intra day: $0.82 \%$. Value of percent recovery were $101.76-105.01 \%$. The phosphorous content of white cabbage 19,344 $\mathrm{mg} / \mathrm{g}$ and $22,116 \mathrm{mg} / \mathrm{g}$, the purple cabbage $16,458 \mathrm{mg} / \mathrm{g}$ and $12,591 \mathrm{mg} / \mathrm{g}$. From these results cabbage white phosphorous content was bigger than the purple cabbage, but levels of Phosphorus is not affected by the color of the cabbage. Cabbage is a food rich in fiber and can be used as an alternative to high food ingredients containing phosphorus.
\end{abstract}

Keywords: Cabbage, phosphorus (p), spectrophotometry. 


\section{Pendahuluan}

Tubuh memerlukan asupan zat gizi seperti air, vitamin, protein, dan mineral dalam jumLah yang cukup agar tetap sehat. Mineral terdapat di dalam tubuh manusia dan memegang peranan penting dalam pemeliharaan fungsi tubuh, baik tingkat sel, jaringan, organ maupun fungsi tubuh secara keseluruhan. Keseimbangan mineral di dalam tubuh diperlukan untuk pengaturan kerja enzim, pemeliharaan keseimbangan asam basa, pemeliharaan kepekaan otot dan saraf terhadap rangsangan (Almatsier, 2009).

Fosfor merupakan mineral kedua terbanyak di dalam tubuh, yaitu $1 \%$ dari berat badan. Kurang lebih $85 \%$ fosfor di dalam tubuh terdapat sebagai garam kalsium fosfat di dalam tulang dan gigi yang tidak dapat larut. Fosfor di dalam tulang berada dalam perbandingan 1:2 dengan kalsium. Fosfor selebihnya terdapat di dalam semua sel tubuh, separuhnya di dalam otot dan di dalam cairan ekstraselular. Sebagai fosfolipid, fosfor merupakan komponen struktural dinding sel. Sebagai fosfat organik, fosfor memegang peranan penting dalam reaksi yang berkaitan dengan penyimpanan atau pelepasan energi dalam bentuk Adenin Trifosfat (ATP) (Almatsier, 2009).

Menurut USDA Nutrient Database (2016) Kandungan Gizi Kubis, mentah, Nilai gizi per $100 \mathrm{~g}(3.5 \mathrm{oz})$ Energi $103 \mathrm{~kJ}$ (25 kcal), Karbohidrat 5,8 g, Lemak 0,1 g, Protein 1,28 g, Vitamin C 36,6 mg (61\%), Kalsium 40 mg (4\%), Besi 0,47 mg (4\%), Magnesium $12 \mathrm{mg}$ (3\%), Fosfor $26 \mathrm{mg}$ (4\%), Kalium $170 \mathrm{mg}$ (4\%), Seng 0,18 mg $(2 \%)$

Kubis merupakan sayuran yang rendah kalori, oleh karena itu makanan ini baik dikonsumsi untuk penurunan berat badan. Kubis juga memiliki sifat anti- inflamasi. Hal ini diyakini bahwa jus kubis membantu dalam mengobati tukak lambung. Kubis juga bermanfaat sebagai pelindung dari radikal bebas, karena kubis memiliki banyak kandungan Vitamin C. Kubis mengandung sejumlah senyawa yang dapat merangsang pembentukan gas dalam lambung sehingga menimbulkan rasa kembung (Anonim 1993 dalam Patty, 2012).

Upaya peningkatan produksi hortikultura di Indonesia semakin meningkat seiring dengan meningkatnya kebutuhan masyarakat terhadap kebutuhan akan gizi. Hal ini disebabkan oleh tingkat pengetahuan masyarakat yang tinggi dan tingkat pendapatan masyarakat yang makin baik. Kebutuhan akan gizi ini salah satunya dapat dipenuhi dengan mengkonsumsi sayuran (Eny, dkk. 2007)

Kubis (Brassica oleracea L) merupakan salah satu tanaman budidaya yang banyak dikonsumsi masyarakat sebagai sayuran yang baik untuk kesehatan karena mengandung mineral dan vitamin yang sangat dibutuhkan tubuh manusia. Mineral yang terkandung dalam kubis antara lain adalah kalsium, besi, fosfor, dan sulfur (Pracaya, 2003).

Sumber fosfor terutama berasal dari hewan dan sumber sintetis seperti bone meal, rock phosphat, dan difluprinated rock phosphat. Sumber fosfor lainnya adalah susu yang merupakan sumber penting dengan kandunga $93 \mathrm{mg}$ persen. Beras giling mengandung fosfor sebanyak 140 mg persen. Daging dan ikan mengandung fosfosr sebanyak 100 - $200 \mathrm{mg}$ persen. (Widodo, 2006)

Sumber fosfor yang utama adalah bahan makanan dengan kadar protein tinggi seperti daging, unggas, ikan, dan telur. Bijibijian terutama bagian lembaganya dan bijibijian yang utuh (pecah kulit) juga banyak mengandung fosfor. Bahan pangan yang kaya protein dan kalsium biasanya juga kaya akan fosfor

Berdasarkan uraian diatas, kubis merupakan bahan makanan yang berpotensi menjadi sumber fosfor, sehingga dilakukan penelitian mengenai analisis kadar fosfor dalam kubis putih dan kubis ungu di daerah lembang bandung. 


\section{Metode Penelitian}

Alat

Alat yang digunakan dalam penelitian ini adalah neraca analitik, labu ukur, pipet volume, pipet ukur, mikro pipet Spektrofotometri UV-Vis Shimadzu 1800.

\section{Bahan}

Bahan yang digunakan pada penelitian ini antara lain kubis ungu dan kubis putih yang diambil dari daerah Lembang Bandung, ammonium molibdat (4\%) p.a, asam sulfat $(5 \mathrm{~N})$ p.a, asam askorbat $(0,1$ M) p.a, kalium antimoniltartat $(0,27 \%)$ p.a, kalium fosfat p.a.

\section{Prosedur}

Kubis putih dan ungu terlebih dahulu dicuci dengan air bersih tiriskan kemudian dipotong potong hingga berukuran lebih kecil, lalu dikeringkan pada suhu $50^{\circ} \mathrm{C}$.

Sampel kubis yang telah kering ditimbang sebanyak 25 gr Sampel dimasukkan ke dalam labu Destruksi dan ditambah $7 \mathrm{~mL} \quad \mathrm{HNO}_{3}$. Labu dekstruksi disambungkan dengan kondensor pendingin. Proses dekstruksi diawali dengan pemanasan hingga $100^{\circ} \mathrm{C}$. Larutan sampel yang telah mendidih didinginkan selama 10 menit, kemudian ditambahkan $2 \mathrm{~mL} \mathrm{H}_{2} \mathrm{O}_{2}(30 \%)$ tetes demi tetes. Sampel dipanaskan lagi secara perlahan pada suhu $200^{\circ} \mathrm{C}$ sampai diperoleh larutan berwarna jernih. Larutan jernih disaring, filtrat ditempatkan dalam labu takar $100 \mathrm{~mL}$ dan diencerkan dengan larutan $\mathrm{HNO}_{3}$ 0,01M hingga tanda batas.

Pembuatan larutan Amonium Molibdat 4\% dilakukan dengan cara menimbang Amonium Molibdat sebanyak 4 gram dilarutkan dalam $100 \mathrm{~mL}$ air suling.

Pembuatan larutan asam sulfat 5,0 N dilakuan dengan cara sebanyak $70 \mathrm{ml}$ asam sulfat 96\% dimasukan dalam labu ukur 100 $\mathrm{ml}$ ditambahkan dengan air suling hingga tanda batas.

Pembuatan Asam Askorbat sebanyak 0,889 gram dimasukan dalam labu ukur 50 $\mathrm{ml}$ ditambahkan air suling hingga tanda batas..

Pembuatan larutan Kalium Antimonil Tartrat sebanyak 0,274 gram dimasukan dalam labu ukur $100 \mathrm{ml}$ dan ditambahkan air suling..

Pembuatan larutan pereaksi dengan cara mengambil larutan ammonium molibdat 4\% sebanyak $15 \mathrm{~mL}$ dicampurkan dengan asam sulfat $5 \mathrm{~N}$ sebanyak $50 \mathrm{~mL}$, lalu ditambahkan dengan $30 \mathrm{~mL}$ larutan asam askorbat, diaduk. Kemudian dicampur dengan $5 \mathrm{~mL}$ larutan kalium antimonil tartrat..

Pembuatan larutan baku Kalium 1000 ppm dilakukan dengan cara sebanyak 71,6 $\mathrm{mg}$ dihidrogen fosfat dimasukan dalam labu ukur $50 \mathrm{ml}$, dilarutkan dengan asam sulfat $0,36 \mathrm{~N}$.

Untuk menentukan panjang gelombang maksimum digunakan larutan standar fosfor $3 \mathrm{ppm}$ dipipet sebanyak $6 \mathrm{~mL}$, lalu dimasukkan kedalam vial dan ditambah $2 \mathrm{~mL}$ larutan campuran, dikocok dan didiamkan selama 15 menit, lalu diukur serapannya secara spektrofotometri visibel pada panjang gelombang 400-800 nm sehingga diperoleh panjang gelombang maksimum.

Kurva kalibrasi larutan baku Fosfat dibuat dengan seri konsentrasi $3 ; 6$; 9; 12; 15 dan 18 ppm. Dari masing masing konsentrasi dipipet sebanyak $6 \mathrm{~mL}$, lalu dimasukkan kedalam vial dan ditambah $2 \mathrm{~mL}$ larutan pereaksi, dikocok dan didiamkan selama 15 menit lalu diukur pada panjang gelombang maksimum. Hasil data pengukuran absorbansi, selanjutnya dibuat kurva standar sehingga diperoleh persamaan $\mathrm{y}=\mathrm{bx}+\mathrm{a}$ untuk menentukan linieritasnya.

Penentuan batas deteksi dan batas kuantisasi dapat di hitung dari kurva kalibrasi dengan menggunakan rumus:

$$
\text { Batas deteksi }=\frac{3 \mathrm{SB}}{\text { Slope }}
$$

Batas deteksi $=10 \mathrm{SB}$

$$
\overline{\text { Slope }}
$$




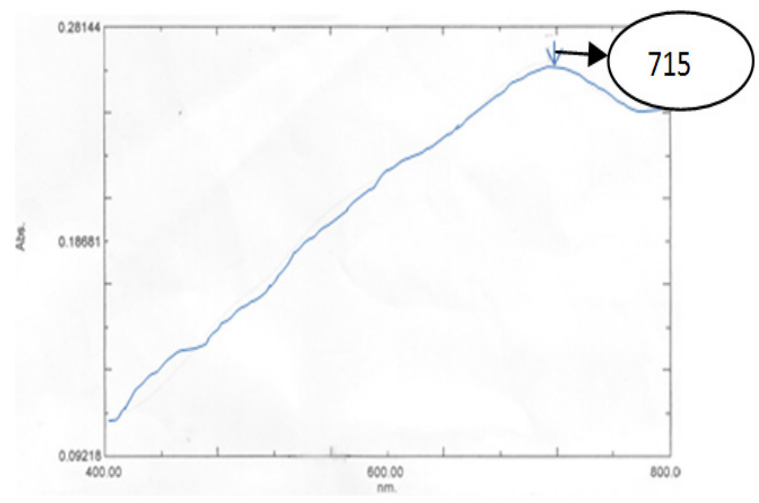

Gambar 1. Spektrum panjang gelombang maksimum

Uji akurasi dan presisi memggunakan metode adisi menyiapkan 5 tabung, masingmasing keonsentasi 1, 2, 3, 4, dan $5 \mu \mathrm{g}$ / $\mathrm{ml}$ dan diukur absorbansinya pada panjang gelombang $714 \mathrm{~nm}$.

Pengukuran kadar sampel dilakukan dengan cara dipipet sebanyak $1 \mathrm{~mL}$ filtrat (hasil destruksi dalam $\mathrm{HNO}_{3}$ dan $\mathrm{H}_{2} \mathrm{O}_{2}$ ), ke dalam tabung reaksi. Ditambahkan 5 $\mathrm{mL}$ aquademineralisasi. Ditambahkan $2 \mathrm{~mL}$ larutan pereaksi warna. Dikocok homogen, tunggu 15 menit, kemudian akan timbul warna. Absorbannya diukur dengan menggunakan alat Spektrofotometri VInterisibel pada panjang gelombang 714 nm. Warna akan stabil selama 5 jam.

\section{Hasil}

Hasil penetapan panjang gelombang maksimumum ditunjukan pada Gambar 1.

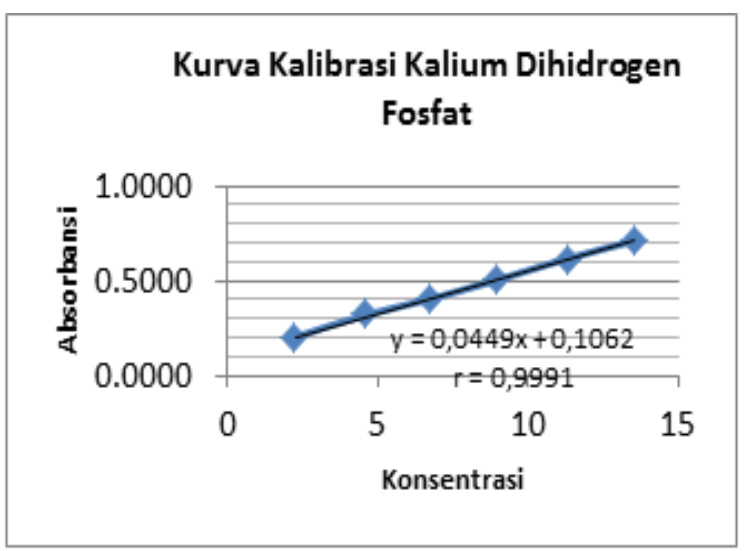

Gambar 3. Kurva kalibrasi larutan fosfat

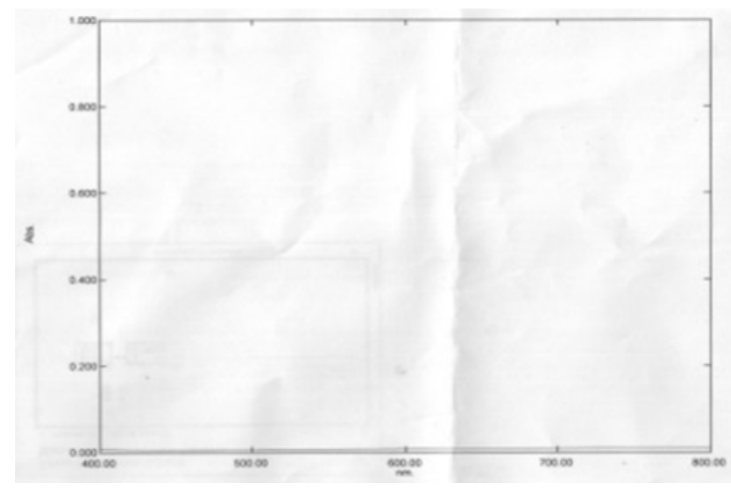

Gambar 2. Spektrum pereaksi warna

Hasil penentuan serapan larutan pereaksi pada panjang gelombang maksimum Fosfat di $714 \mathrm{~nm}$ diperlihatkan pada gambar 2. Hasil analisis kurva kalibrasi larutan fosfat dapat ditunjukan pada gambar 3 . Berdasarkan Persamaan di dalam kurva kalibrasi, linieritas, batas deteksi dan batas kuantisasi. Hasil batas deteksi dan batas kuantisasi fosfor dapat dilihat pada tabel 1.

Kecermatan (akurasi) adalah ukuran yang menunjukkan derajat kedekatan hasil analis dengan kadar analit yang sebenarnya. Kecermatan dinyatakan sebagai persen perolehan kembali (recovery) analit yang ditambahkan.

Akurasi dilakukan dengan menggunakan metode standar adisi. Metode standar adisi dapat dilakukan dengan menambahkan sejumlah analit dengan konsentrasi tertentu pada sampel yang

Tabel 1. Hasil Penentuan Linieritas, Batas Deteksi dan batas Kuantisasi

\begin{tabular}{ccc}
\hline Parameter & Hasil & Syarat \\
\hline Persamaan Reg & $\mathrm{y}=0,0449 \mathrm{x}+$ & \\
Lin & 0,1062 & \\
Slop & 0,0449 & \\
Intersep & 0,1062 & \\
Rata-rata & 7,875 & \\
Sy/x & 0,005631285 & \\
(Sy/x)/b & 0,125418383 & \\
R linieritas & 0,9991 & mendekati 1 \\
LOD & 0,3766255148 & \\
LOQ & 1,254183826 & \\
V x 0 & 0,015926144 & $<5 \%$ \\
\hline
\end{tabular}


Tabel 2. Hasil Penentuan Presisi inter day dan intra day

\begin{tabular}{rrrrrrr}
\hline \multirow{2}{*}{ No } & \multicolumn{3}{c}{ Pengujian } & \multicolumn{3}{c}{ Konsentrasi Fosfor $(\boldsymbol{\mu g} / \mathbf{m l})$} \\
\cline { 2 - 7 } & Hari 1 & Hari 2 & Hari 3 & 1 & 2 & 3 \\
\hline 1 & 0,288 & 0,287 & 0,288 & 3,119749 & 3,101920 & 3,119749 \\
2 & 0,288 & 0,287 & 0,286 & 3,119749 & 3,101920 & 3,084090 \\
3 & 0,287 & 0,289 & 0,285 & 3,101920 & 3,137579 & 3,066260 \\
4 & 0,287 & 0,289 & 0,284 & 3,101920 & 3,137579 & 3,048430 \\
5 & 0,285 & 0,290 & 0,285 & 3,066260 & 3,155409 & 3,066260 \\
\multicolumn{1}{r}{6} & 0,286 & 0,288 & 0,285 & 3,084090 & 3,119749 & 3,066260 \\
Rata-rata & & & & 3,098948 & 3.125693 & 3.07517466 \\
SD & & & & 0.020844 & 0.021593 & 0.02457681 \\
$(\%)$ KV & & & & 0.672614 & 0.690825 & 0.79920051 \\
\hline
\end{tabular}

diperiksa, lalu dianalisis dengan metode tersebut. Hasil Standar Deviasi (SD) yang diperoleh adalah : 0,$51 ; 0,34 ; 0,25$; 0,35 . Sedangkan hasil perolehan kembali yang didapat adalah : 101,94\%; 101,76\%; $86,33 \% ; 105,01 \%$. Semua hasil tersebut memenuhi syarat jika berada pada rentang $80 \%$ - 120\% (Harmita 2004).

Penentuan kadar fosfat dalam kubis putih dan ungu dianalisis dengan Spektrofotometri Visibel. Hasil penentuan kadar fosfor pada sampel tersebut dapat ditunjukan pada tabel 4.

\section{Pembahasan}

Kubis merupakan sampel biologis yang mengandung banyak serat dan matriks. Agar fosfor tersebut bisa dianalasis maka fosfor tersebut harus dilepaskan dahulu dari matriksnya menjadi bentuk bebasnya agar dapat terdeteksi pada saat analisis. dengan panjang gelombang yang spesifik. Metode yang digunakan adalah metode destruksi yaitu dengan memutuskan ikatan unsur logam dengan komponen lain dalam matriks sehingga unsur tersebut berada dalam keadaan bebas kemudian dianalisis menggunakan spektrofotometri uv-vis. Pada Spektrofotometri uv-vis, pengukuran absorbansi atau konsentrasi dibuat berdasarkan seri larutan pada panjang gelombang yang telah ditetapkan. Panjang gelombang yang paling sesuai ditentukan dengan membuat spektrum absorbsi dimana panjang gelombang yang paling sesuai adalah yang menghasilkan absorbansi maksimum. Dengan menggunakan panjang gelombang dari absorbansi yang maksimum, maka jika terjadi penyimpangan (deviasi) kecil panjang gelombang dari cahaya masuk hanya akan menyebabkan kesalahan yang kecil dalam pengukuran tersebut

Setiap senyawa kimia memiliki panjang gelombang yang berbeda-beda (spesifik). Sehingga harus di lakukan pengujian panjang gelombang terlebih dahulu agar diketahui panjang gelombang senyawa yang kita uji sesuai tidak dengan literatur. Suatu unsur atau senyawa akan menyerap cahaya lebih kuat pada panjang gelombang tertentu, dan absorbansi akan maksimum apabila diukur pada panjang gelombang maksimum. Fosfor memiliki rumus kimia tunggal yaitu $\mathrm{P}$, agar fosfor tersebut dapat dianalisis dengan spektrofotometri uv-vis maka harus ditambahkan pereaksi warna. Fosfor memiliki panjang gelombang berkisar antara 670-720 nm (Randel, et al 2007). Menyebutkan dalam penelitiannya pamjang gelombang maksimum Fosfat menggunakan pereaksi warna pada panjang gelombang $720 \mathrm{~nm}$. Hasil yang diperoleh pada penelitian ini sesuai dengan literature yaitu $714 \mathrm{~nm}$ dapat dilihat pada gambar 1 .

Linearitas adalah kemampuan metode analisis yang memberikan respon secara langsung atau adanya hubungan antara 
Tabel 3. Hasil Penentuan Perolehan Kembali

\begin{tabular}{|c|c|c|c|c|c|c|c|c|}
\hline No & $\begin{array}{l}\text { Konsen } \\
\text { trasi }\end{array}$ & $\begin{array}{c}\text { Absor } \\
\text { bansi }\end{array}$ & $\begin{array}{l}\text { Kadar terukur } \\
(\mu \mathrm{g} / \mathrm{ml})\end{array}$ & \% Recovery & $\begin{array}{c}\text { Rataan Kadar } \\
(\mu \mathrm{g} / \mathrm{ml})\end{array}$ & $\begin{array}{l}\text { Rataan \% } \\
\text { Recovery }\end{array}$ & SD & KV \\
\hline 1 & 0 & 0,114 & & & & & & \\
\hline \multirow[t]{3}{*}{2} & 2 & 0,229 & 2,033 & 101,647 & & & & \\
\hline & & 0,229 & 2,033 & 101,647 & 2,03883 & 101,941 & 0,510 & 0,501 \\
\hline & & 0,230 & 2,051 & 102,531 & & & & \\
\hline \multirow[t]{3}{*}{3} & 3 & 0,287 & 3,058 & 101,942 & & & & \\
\hline & & 0,287 & 3,058 & 101,942 & 3,05235 & 101,745 & 0,340 & 0,334 \\
\hline & & 0,286 & 3,041 & 101,352 & & & & \\
\hline \multirow[t]{3}{*}{4} & 4 & 0,309 & 3,447 & 86,179 & & & & \\
\hline & & 0,310 & 3,465 & 86,621 & 3,45305 & 86,326 & 0,255 & 0,296 \\
\hline & & 0,309 & 3,447 & 86,179 & & & & \\
\hline \multirow[t]{3}{*}{5} & 5 & 0,412 & 5,268 & 105,359 & & & & \\
\hline & & 0,410 & 5,233 & 104,652 & 5,25028 & 105,006 & 0,354 & 0,337 \\
\hline & & 0,411 & 5,250 & 105,006 & & & & \\
\hline
\end{tabular}

konsentrasi dan absorbansi. konsentrasi analit dalam sampel (Harmita, 2004).

Kurva kalibrasi diperoleh dari suatu persamaa garis linier yaitu $\mathrm{y}=0,0449 \mathrm{x}$ $+0,1062$. Persamaan tersebut memiliki koefisien korelasi (r) yang mendekati 1 yakni 0,9991 menunjukan adanya korelasi yang menyaakan adanya hubungan antara X (konsentrasi) dan Y (absorbansi). Hal ini memiliki arti bahwa persamaan tersebut dapat digunakan untuk menentukan nilai atau kadar sampel.

Penentuan batas deteksi dan batas kuantisasi dengan menggunakan data kurva kalibrasi larutan baku fosfat dengan mencari simpangan baku residual (sy/x) Nilai terkecil yang dapat dideteksi (LOD) dan masih dapat memberikan respon yang signifikan yaitu $0,38 \mu \mathrm{g} / \mathrm{mL}$.

Batas kuantitasi (LoQ) ditentukan dari persamaan LoQ $=(10 \mathrm{sy} / \mathrm{x}) /$ slope . Batas kuantitas menunjukkan kuantitasi konsentrasi terendah analit yang pasti terdeteksi secara kuantitatif. Batas kuantitas (LoQ) sesuai persamaan kurva kalibrasi standar fosfor adalah $1,254 \mu \mathrm{g} / \mathrm{mL}$. Nilai koefisien fungsi regresi (Vx0) yang dihasilkan adalah 0,016 .

Keseksamaan (presisi) adalah ukuran yang menunjukkan derajat kesesuaian antara hasil uji individual, diukur melalui penyebaran hasil individual dari rata-rata jika prosedur diterapkan secara berulang pada sampel-sampel yang diambil dari campuran yang homogenya (Harmita, 2004).

Uji keseksamaan (presisi) dilakukan dengan dua metode yaitu intraday dan inter day. Intraday merupakan pengulangan yang dilakukan dalam satu hari, sedangkan interday merupakan pengulangan yang dilakukan pada hari berbeda selama beberapa hari.

Nilai presisi dilihat dari nilai koefisien

Tabel 4 Hasil Penentuan Kadar Fosfor Pada Sampel

\begin{tabular}{ccccc}
\hline Sampel & Bobot Sampel & Absorbansi & Kadar Fosfor (mg/g) & $\begin{array}{c}\text { Kadar Rata-rata Fosfor } \\
(\mathbf{m g} / \mathbf{g})\end{array}$ \\
\hline Kubis Putih & 25,099 & 0,455 & 19,344 & 20,725 \\
& 25,100 & 0,505 & 22,116 & \\
Kubis Ungu & 25,103 & 0,403 & 16,458 & 14,525 \\
& 25,073 & 0,333 & 12,591 & \\
\hline
\end{tabular}


variasi. Setelah dilakukan perhitungan, nilai presentase koefisien variasinya (KV) sudah memenuhi syarat yang telah ditentukan yaitu untuk inter day hari pertama: $0,67 \%$; hari kedua: $0,60 \%$; hari ketiga $=0,80 \%$. dan untuk hasil intra day: 0,82\%, dimana nilai presentase koefisien variasinya $<2 \%$ (Harmita, 2004).

Analisis fosfor di dalam kubis menggunakan metode Spektrophotometri visible., pereaksi amonium molibdat dan kalium antimonil tartarat bereaksi dalam medium asam dengan larutan sampel membentuk kompleks antimonyl fosfomolibdat yang akan direduksi menjadi kompleks biru-molibdem (molybdenum blue) oleh asam askorbat. Metode ini dapat digunkaan untuk berbagai tipe sempel dan berdasarkan table 5 kadar fosfor pada sampel kubis putih lebih besar di bandingkan didalam kubis ungu yaitu kubis putih.

\section{Kesimpulan}

Kadar fosfor dalam kubis putih adalah $20,725 \mathrm{mg} / \mathrm{g}$. Kadar fosfor dalam kubis ungu adalah 14,525 mg/g. Berdasarkan hasil yang didapat terdapat perbedaan kadar fosfor dalam kubis putih dan kubis ungu yaitu lebih besar di dalam kubis putih dibandingkan dengan kubis ungu tetapi perbedaan kadar fosfor dari kedua kubis tersebut tidak dipengaruhi oleh warna dari kubis. Dengan demikian kubis putih dapat dijadikan sebagai alternatif bahan makanan kaya serat yang mengandung fosfor karena kadar fosfor didalamnya cukup tinggi.

\section{Daftar Pustaka}

[1] Almatsier, Sunita., 2009, Prinsip Dasar Ilmu Gizi, Jakarta : PT Gramedia Pustaka Utama, (243-246).

[2] Cashman, K.D., 2002, Calcium Intake, Calcium Bioavailability and Bone Health, British Journal of Nutrition. 87, Suppl.2, S169-S177.

[3] Departemen Kesehatan R.I., 1981.
Daftar Komposisi Bahan Makanan Direktorat Gizi DepKes R.I. Bhratara Karya Aksara, Jakarta.

[4] Eny Dyah Y. Ivan K dan Ira Y. 2007. Pemberian Berbagai Konsentrasi Algifert Sebagai Upaya Pe ningkatan Hasil Tanaman Brokoli. Bul. Vol 3 No 1: 63-75.

[5] Farid A. F, Neda A, F (2014) Evaluation and Determination of mineral content in fruit. Departement of Food Science and Tecnologi International Journal of plant, animal and Eviromental Scient. Vol 4

[6] Harmita, 2004, Petunjuk Pelaksanaan Validasi Metode dan Cara Perhitungannya, Departemen Farmasi FMIPA-UI.

[7] Institute of Medicine, 1997, Dietary Reference Intakes for Calcium, Phosphorus, Magnesium, Vitamin D, and Fluoride", National Academy Press, 1997, p. $151-152$.

[8] Patty, J.A. 2012. Peran Tanaman Aromatik Dalam Menekan Perkembangan Hama Spodoptera litura Pada Tanaman Kubis, Jurusan Budidaya Pertanian Fakultas Pertanian Unpatti, Ambon.

[9] Suprihatin., Perwitasari, Dyah Suci., 2010, Pembuatan Asam Laktat dari Limbah Kubis, Jurusan Teknik Kimia FakultasTeknologi Industri UPN"Veteran", JawaTimur.

[10] Widodo, W (2006) Pengantar ilmu Nutrisi Ternak. Fakultas Peternakan-perikanan Universitas Muhammadiyah Malang (UMM) 